\begin{tabular}{l|c|r}
\hline ISSN: 0001-5113 & ACTA ADRIAT., & SHORT COMMUNICATION \\
AADRAY & $60(1): 91-98,2019$ & \\
\hline
\end{tabular}

\title{
Additional findings of Albunea carabus (Linnaeus, 1758) (Decapoda, Anomura, Hippoidea) in Italian waters
}

\author{
Bruno ZAVA ${ }^{1,2}$, Gianni INSACCO ${ }^{2}$ and Maria CORSINI-FOKA ${ }^{3 *}$ \\ ${ }^{1}$ Wilderness studi ambientali, via Cruillas 27, 90146 Palermo, Italy \\ ${ }^{2}$ Museo Civico di Storia Naturale, via degli Studi 9, 97013 Comiso (RG), Italy \\ ${ }^{3}$ Hellenic Centre for Marine Research, Institute of Oceanography, Hydrobiological Station of \\ Rhodes, Cos Street, 85100 Rhodes, Greece \\ *Corresponding author, e-mail: mcorsini@hcmr.gr
}

The first findings of the anomuran Albunea carabus (Linnaeus, 1758) from the southeastern coasts of Sicily are documented, improving knowledge on the distribution of this poorly known species around the island and in the Mediterranean Sea. The distribution of records in the whole basin is updated.

Key words: Crustacea, Anomura, Albunea carabus, Sicily, Mediterranean Sea

\section{INTRODUCTION}

The sand crab Albunea carabus (Linnaeus, 1758) (Decapoda, Anomura, Hippoidea) is the single species of the family Albuneidae living in the Mediterranean Sea. It is known from the eastern Atlantic and the Mediterranean Sea, mainly from its western coasts, such as those of Italy, Spain, Algeria, Tunisia (BOYKO, 2002; PEREIRA et al., 2008). The species was considered rare in the past, especially in the eastern part of the Mediterranean, but recent records confirmed the "apparent rarity" of $A$. carabus, as expected by BOYKO (2002). In fact, apart the already known occurrence documented in Israel, Lebanon and the southern coasts of Turkey (HOLTHUIS \& GOTTLIEB, 1958; BOYKO, 2002; KATAĞAN \& ÇEVIK, 2003), A. carabus has been recently reported for the first time from the Aegean waters (CORSINI-FOKA \& KALOGIROU, 2013) and along the Egyptian Mediterranean coasts (ABDELSALAM \& RAMADAN, 2017), widening noticeably the knowledge of the geographical distribution of this sand crab in the eastern Mediterranean Sea.

Few scattered findings of $A$. carabus have been documented from Italy: in the Tyrrhenian Sea, namely along the coasts of Lazio (MONCHARMONT, 1969), also along the northeastern coasts of Sicily, at Mortelle, Messina, four specimens, and the western coasts of Calabria, one specimen, in 1992 (GIACOBBE \& SPANÒ, 1996); also reported from the Sardinian Channel in 1997-2002 (MURA \& CORDA, 2011) and from the Strait of Sicily, along the southwestern coast of Sicily, at Marinella, two specimens, in 1996 (SPANÒ et al., 1999), while recently it has been 
recorded from the eastern waters of the island (SCUDERI et al., 2017). As reported in HOLTHUIS (1954) and GIACOBBE \& SPANÒ (1996), RAFINESQUE (1814) has recorded the species from Sicily, but he did not mention the precise locality. Constantine Samuel Rafinesque Schmaltz was employed as secretary to the U.S. Consul in Sicily Mr. Abraham Gibbs, who was a banker as well a merchant. Since he could speak French, English and Italian, besides enjoying a good position in the consulate in Palermo, Rafinesque was a privileged man and he could devote all his free time to his interests in natural history. His acquaintance with the English naturalist William Swainson, who was posted in nearby Messina in the Commissary of Accounts Department of the British Army, was greatly important. Rafinesque and Swainson undertook several excursions in the outskirts of Palermo from 1807 to 1812 in order to botanize and to collect insects, marine creatures and birds. Thanks to their common interests in natural history research they developed a friendly relationship which continued until 1840 with mutual exchange of letters, news and specimens. Many specimens of marine creatures were given by William Swainson to Rafinesque for study and description (Charles Boewe 2000, in litteris); we are convinced that the specimen of "Albunea symnista" Fabricius mentioned by RAFINESQUE (1814) could have been collected most likely on the beach of Mortelle, Messina (SWAINSON, 1989).

The species burrows into sandy environment at depth from a few meters down to 50-60 m, mainly in habitat characterized by high turbidity and remarkable hydrodynamism (GIACOBBE \& SPANÒ, 1996; SPANÒ et al., 1999) and, like cofamiliar species, presents pelagic larval phases (SERIDJI, 1988; MURPH \& FAULKES, 2013).

In the present study, new information on the distribution of $A$. carabus in the waters of southern Sicily and the Tyrrhenian Sea is given through the report of findings carried out in the last two decades. The distribution of records of the species in the Mediterranean waters is furthermore updated.

\section{MATERIAL AND METHODS}

Three individuals of $A$. carabus were collected by trammel-nets in the waters of southeastern Sicily and identified following BOYKO (2002). The specimens were deposited at the Museo Civico di Storia Naturale di Comiso (Province of Ragusa) (MSNC), under the catalogue number MSNC 4553. Carapace length CL, carapace width $(\mathrm{CW})$ and length of abdominal somites and telson STL were measured under a stereomicroscope by use of a caliper to the nearest $0.01 \mathrm{~mm}$, following KATAĞAN \& ÇEVIK (2003). Carapace length CL was measured from the midpoint of the anterior margin (including rostrum) to the midpoint of the posterior concavity; carapace width $\mathrm{CW}$ was measured as the distance between the lateral anterior margins of the carapace; the length of abdominal somites and telson STL was measured from the anterior margin of the first somite to the posterior tip of telson. Sex was determined under a stereomicroscope, by observing the position of the gonopores (on the coxa of the third pereiopod in females or the coxa of the fifth pereiopod in males) (BOYKO, 2002).

A fourth specimen $(P)$ has been collected by a private citizen during summer 2012 at the beach of Tre Fontane, Campobello di Mazara (Trapani), southwestern coast of Sicily. Another specimen of unknown sex was captured on 22 May 2018 at Agropoli (Province of Salerno, Campania), southern Tyrrhenian Sea, with trammel-net, on sandy bottom. Apart photographic documentation, no other information is available for these last two findings.

The Mediterranean findings of the species, including those newly reported here, are listed in Table 1 and their distribution is given in Fig. 1.

\section{RESULTS AND DISCUSSION}

A male of $A$. carabus, MSNC 4553-1 (Fig. 2a), CL $16.2 \mathrm{~mm}, \mathrm{CW} 19.6 \mathrm{~mm}$, telson partially damaged, was collected on 3 May 2000 on sandy bottom at $8 \mathrm{~m}$ of depth, at $300 \mathrm{~m}$ distance from the mouth of Irminio river (Ragusa) $\left(36^{\circ}\right.$ $\left.46.381^{\prime} \mathrm{N}, 14^{\circ} 35.065^{\prime} \mathrm{E}\right)$. After seventeen years, 


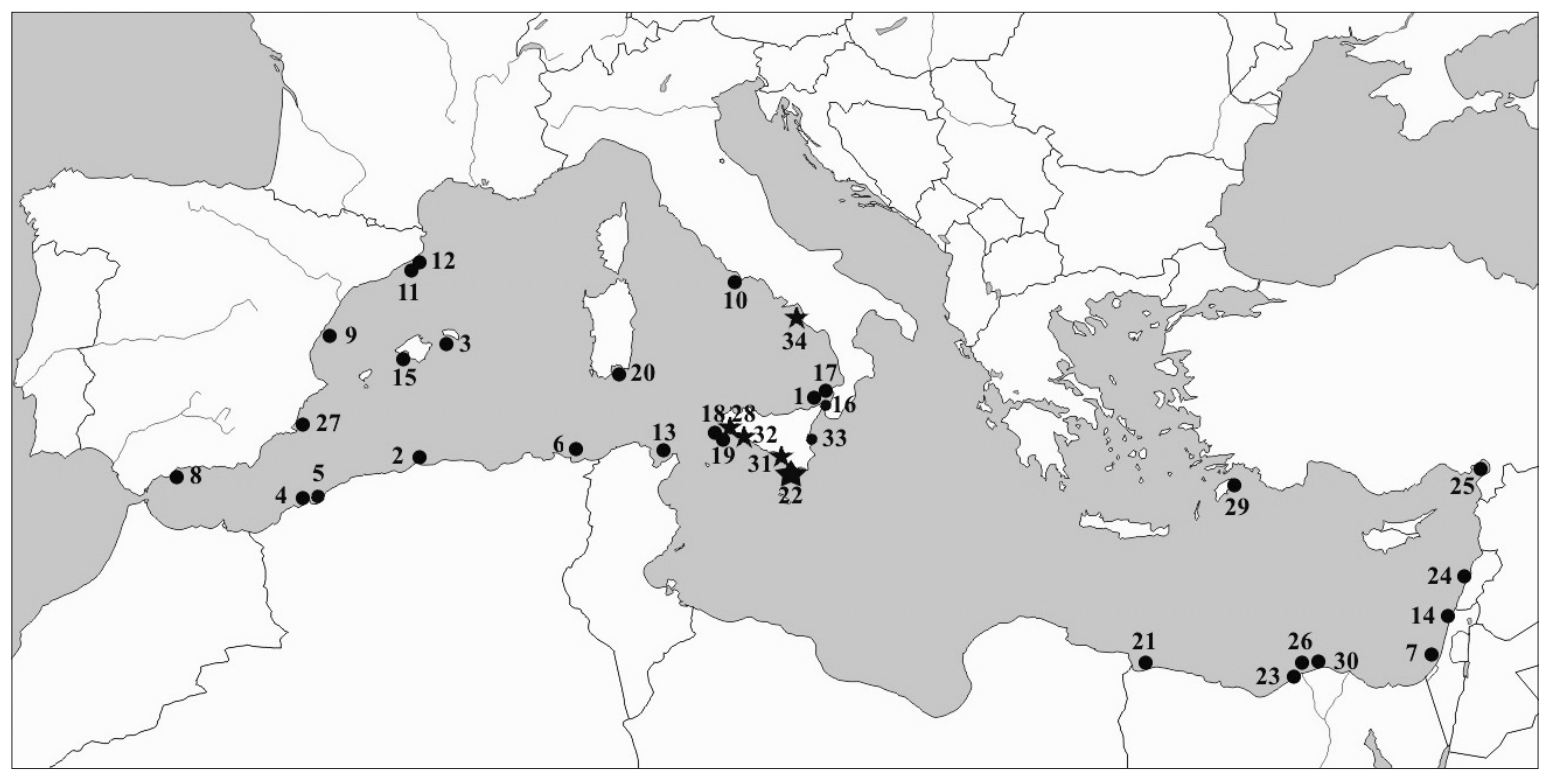

Fig. 1. Locations of records of Albunea carabus in the Mediterranean $(\bullet$, previous records, $\star$ present study). Details in Table 1

a second specimen, female, MSNC 4553-2, CL $16.6 \mathrm{~mm}$, CW $18.5 \mathrm{~mm}$, STL $17.2 \mathrm{~mm}$, weight 4 $\mathrm{g}$, was found on 15 April 2017 on sandy bottom at $6-7 \mathrm{~m}$ of depth, at $300 \mathrm{~m}$ distance from the mouth of Irminio river as above $\left(36^{\circ} 46.229^{\prime} \mathrm{N}\right.$, $\left.14^{\circ} 35.491^{\prime} \mathrm{E}\right)$. A third specimen, an ovigerous female, MSNC 4553-3 (Fig. 2b, c), CL 20.3 $\mathrm{mm}$, CW $2.8 \mathrm{~mm}$, STL $20.8 \mathrm{~mm}$, weight $8 \mathrm{~g}$, was detected on 5 May 2017 on sandy bottom at $8 \mathrm{~m}$ of depth, at $300 \mathrm{~m}$ distance from the Sailing
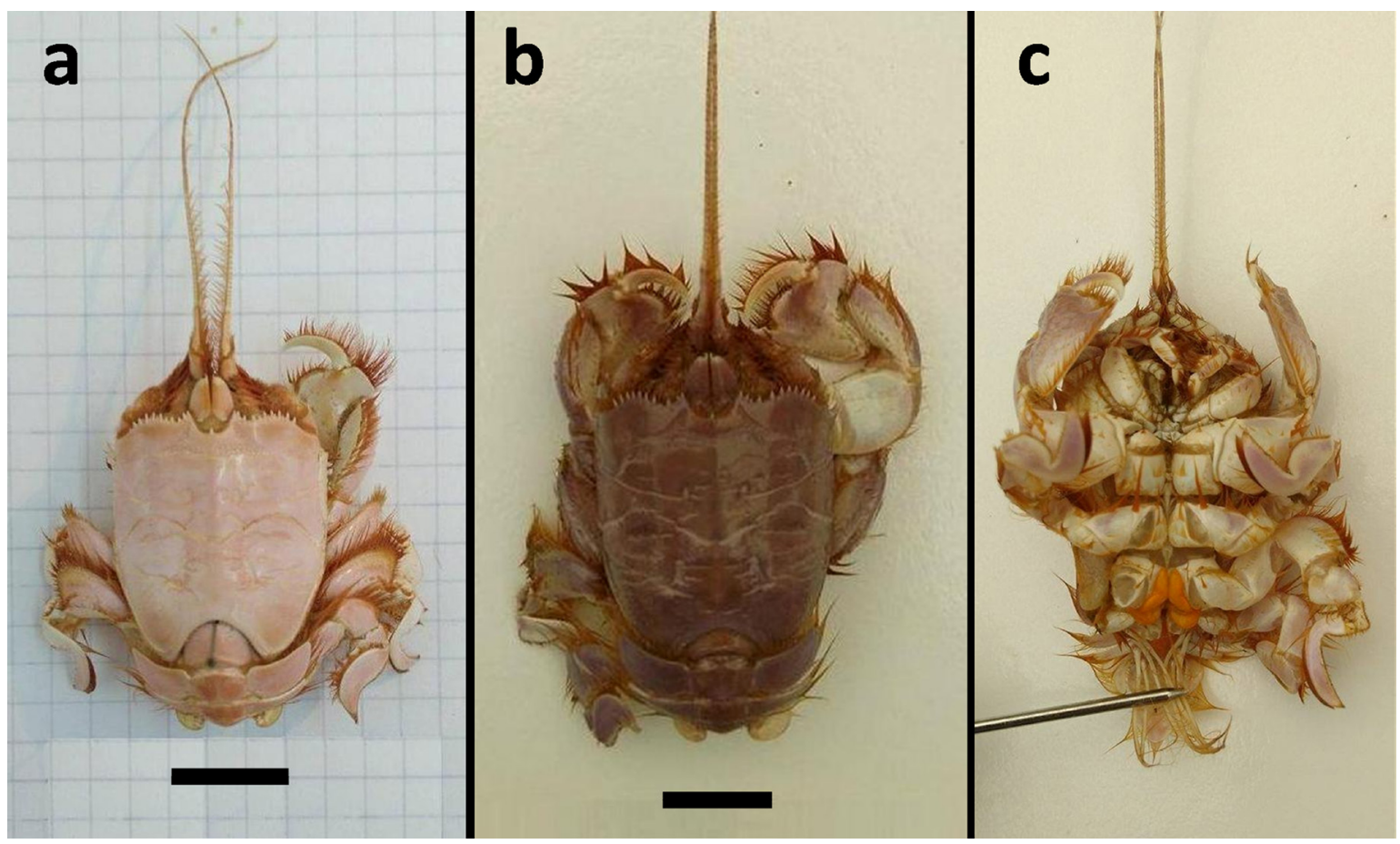

Fig. 2. Albunea carabus from Italy: the preserved specimen MSNC 4553-1 (Carapace length $16.2 \mathrm{~mm}$ ) collected off the outlet of Irminio river, Sicily, May 2000 (a), and the fresh ovigerous female MSNC 4553-3 (Carapace length $20.3 \mathrm{~mm}$ ), collected off Marina di Ragusa, Sicily, May 2017 (b: dorsal view, c: ventral view). Black bar: $10 \mathrm{~mm}$ 
Table 1. Updated Mediterranean records of Albunea carabus (modified from Pereira et al., 2008). (N: Number of specimens; ID: number of location records shown in Fig. 1; * Date of publication)

\begin{tabular}{|c|c|c|c|c|c|c|c|c|}
\hline Region & $\begin{array}{l}\text { Year of } \\
\text { finding }\end{array}$ & Latitude & Longitude & N/Sex & $\begin{array}{c}\mathrm{CL} \\
(\mathrm{mm})\end{array}$ & $\begin{array}{l}\text { Depth } \\
\text { (m) }\end{array}$ & Reference & ID \\
\hline Italy (Sicily) & 1814 & & & & & & Rafinesque (1814) & 1 \\
\hline \multirow{3}{*}{$\begin{array}{l}\text { Algeria (Cap Matifou, } \\
\text { Alger) }\end{array}$} & $1840-1842$ & & & 5 & & & Lucas (1849) & 2 \\
\hline & & & & & & & & \\
\hline & 1850 & & & 12 & & $30-40$ & Lucas (1853) & 2 \\
\hline Spain (Menorca) & $1874 *$ & & & & & & $\begin{array}{l}\text { Larrinùa y Azcona } \\
\text { (1874), Bolivar (1875) }\end{array}$ & 3 \\
\hline \multirow[t]{2}{*}{ Algeria (Oran) } & 1881 & & & $2 \delta^{\pi}$ & $12.1-13.3$ & & $\begin{array}{l}\text { Milne-Edwards \& } \\
\text { Bouvier (1900) }\end{array}$ & 4 \\
\hline & & & & 19 & 18.6 & & & 4 \\
\hline Algeria (Gulf of Oran) & 1900 & & & $1+$ & 20.7 & & $\begin{array}{l}\text { Milne-Edwards \& } \\
\text { Bouvier (1900) }\end{array}$ & 5 \\
\hline Algeria (Rade de Bône) & 1908 & & & 3 우 & $13.9-18.1$ & $15-20$ & Boyko (2002) & 6 \\
\hline Israel (Nahr-Rubin) & 1920 & & & 19 & 14.7 & & Aharoni (1937) & 7 \\
\hline Spain (Malaga) & $1933 *$ & & & & & & Miranda Rivera (1933) & 8 \\
\hline $\begin{array}{l}\text { Spain (Playa de Castellón, } \\
\text { Valencia) }\end{array}$ & $1961 *$ & & & $10 \hat{n}, 1$ 우 & & & Zariquiey-Alvarez (1961) & 9 \\
\hline \multirow{3}{*}{$\begin{array}{l}\text { Italy (Lazio-eastcentral } \\
\text { Tyrrhenian Sea) }\end{array}$} & 1969 & $14^{\circ} 15^{\prime} \mathrm{N}$ & $13^{\circ} 36^{\prime} \mathrm{E}$ & $3 \overbrace{}^{\lambda}$ & $16.5-19$ & $3-4$ & Moncharmont (1969) & 10 \\
\hline & & & & & & & & \\
\hline & & & & $1+$ & 22.5 & & & 10 \\
\hline $\begin{array}{l}\text { Spain (Arenys de Mar, } \\
\text { Barcelona) }\end{array}$ & 1971 & & & $10^{\pi}$ & 18.6 & $3-7$ & $\begin{array}{l}\text { Rubió \& Holthuis } \\
\text { (1972) }\end{array}$ & 11 \\
\hline $\begin{array}{l}\text { Spain (Canet de Mar, } \\
\text { Barcelona) }\end{array}$ & 1972 & & & $2{ }^{\lambda}$ & $18.1-19.2$ & 5 & Rubió \& Holthuis (1972) & 12 \\
\hline \multirow{3}{*}{$\begin{array}{l}\text { Spain (Arenys de Mar, } \\
\text { Barcelona) }\end{array}$} & $1972-1973$ & & & $4 \widehat{\diamond}$ & $19.1-21$ & $3-6$ & Boyko (2002) & 11 \\
\hline & & & & & & & & \\
\hline & 1973 & & & $2 \overbrace{}^{\lambda}$ & $18-19.5$ & $4-5$ & & 11 \\
\hline Tunisia & 1973 & & & $10^{\pi}$ & 16.5 & & Rubió \& Holthuis (1972) & 13 \\
\hline $\begin{array}{l}\text { Spain (Arenys de Mar, } \\
\text { Barcelona) }\end{array}$ & 1974 & & & $10^{\pi}$ & 20.3 & $3-6$ & Boyko (2002) & 11 \\
\hline Israel (Haifa Bay) & 1987 & & & $1+$ & 16.5 & & Boyko (2002) & 14 \\
\hline Spain (Majorca) & $1988^{*}$ & & & & & & $\begin{array}{l}\text { Garcia Socias \& Gracia } \\
\text { (1988) }\end{array}$ & 15 \\
\hline \multirow[t]{2}{*}{$\begin{array}{l}\text { Italy (northeastern Sicily- } \\
\text { south Tyrrhenian Sea) }\end{array}$} & 1992 & $38^{\circ} 16,7^{\prime} \mathrm{N}$ & $15^{\circ} 36,3^{\prime} \mathrm{E}$ & $3{ }^{\pi}$ & $20-25$ & 5 & $\begin{array}{l}\text { Giacobbe \& Spanò } \\
\text { (1996) }\end{array}$ & 16 \\
\hline & & & & 1 우 & 23 & & & 16 \\
\hline $\begin{array}{l}\text { Italy (western coasts of } \\
\text { Calabria-south Tyrrhenian } \\
\text { Sea) }\end{array}$ & 1992 & $38^{\circ} 26,1^{\prime} \mathrm{N}$ & $15^{\circ} 52,8^{\prime} \mathrm{E}$ & $10^{\pi}$ & 23 & 20 & $\begin{array}{l}\text { Giacobbe \& Spanò } \\
\text { (1996) }\end{array}$ & 17 \\
\hline \multirow{2}{*}{$\begin{array}{l}\text { Italy (southwestern Sicily- } \\
\text { Strait of Sicily) }\end{array}$} & 1996 & $37^{\circ} 35,38^{\prime} \mathrm{N}$ & $12^{\circ} 50,22^{\prime} \mathrm{E}$ & $10^{\pi}$ & 13 & 2,5 & Spanò et al. (1998) & 18 \\
\hline & 1996 & $36^{\circ} 50,43^{\prime} \mathrm{N}$ & $14^{\circ} 27,22^{\prime} \mathrm{E}$ & 19 & 15 & 5 & & 19 \\
\hline
\end{tabular}




\begin{tabular}{|c|c|c|c|c|c|c|c|}
\hline $\begin{array}{l}\text { Italy (southeast Sardinia- } \\
\text { Sardinian Channel) }\end{array}$ & $1997-200$ & & & & & Mura \& Corda (2011) & 20 \\
\hline Egypt (Sidi Barrani) & 2000 & & $1 \delta^{\pi}$ & & $65-66$ & $\begin{array}{l}\text { Abdelsalam \& Ramadan } \\
\text { (2017) }\end{array}$ & 21 \\
\hline Italy (southeastern Sicily) & 2000 & $36^{\circ} 46,381^{\prime} \mathrm{N} 14^{\circ} 35,065^{\prime} \mathrm{E}$ & $1 \delta^{\pi}$ & 16.2 & 8 & Current study & 22 \\
\hline $\begin{array}{l}\text { Egypt (Qayet Bey, } \\
\text { Alexandria) }\end{array}$ & 2001 & & $10^{\pi}$ & 18.9 & 7,5 & $\begin{array}{l}\text { Abdelsalam \& Ramadan } \\
\text { (2017) }\end{array}$ & 23 \\
\hline Lebanon (Beirut) & $2002 *$ & & $2 q$ & $16.3-16.6$ & & Boyko (2002) & 24 \\
\hline $\begin{array}{l}\text { Turkey (Iskenderun- } \\
\text { northeastern Mediterranean) }\end{array}$ & 2002 & $36^{\circ} 30,00^{\prime} \mathrm{N} \quad 35^{\circ} 20,67^{\prime} \mathrm{E}$ & $1 \delta^{\lambda}$ & 19 & 25 & Katağan \& Çevik (2003) & 25 \\
\hline $\begin{array}{l}\text { Egypt (Eastern Harbor of } \\
\text { Alexandria) }\end{array}$ & 2002 & & $10^{\pi}$ & & 11 & $\begin{array}{l}\text { Abdelsalam \& Ramadan } \\
\text { (2017) }\end{array}$ & 26 \\
\hline Spain (Murcia) & 2012 & & 1 & & & Puerta C.* & 27 \\
\hline Italy (southwestern Sicily) & 2012 & & 1 우 & & & $\begin{array}{l}\text { Current study } \\
\text { (Passannante C., pers. } \\
\text { comm.) }\end{array}$ & 28 \\
\hline Greece (Rhodes) & 2012 & & 1 우 & 18.6 & 50 & $\begin{array}{l}\text { Corsini-Foka \& } \\
\text { Kalogirou (2013) }\end{array}$ & 29 \\
\hline Egypt (Abu Qir) & 2015 & & $1 \delta^{\pi}$ & & 21 & $\begin{array}{l}\text { Abdelsalam \& Ramadan } \\
\text { (2017) }\end{array}$ & 30 \\
\hline Italy (southeastern Sicily) & 2017 & $36^{\circ} 46,229^{\prime} \mathrm{N} 14^{\circ} 35,491^{\prime} \mathrm{E}$ & 1 우 & 16.6 & $6-7$ & Current study & 31 \\
\hline Italy (southeastern Sicily) & 2017 & $36^{\circ} 46,696^{\prime} \mathrm{N} 14^{\circ} 33,698^{\prime} \mathrm{E}$ & $1+$ & 20.3 & $6-7$ & Current study & 32 \\
\hline Italy, Sicily (Ionian Sea) & 2017 & & many & & & Scuderi et al. (2017) & 33 \\
\hline $\begin{array}{l}\text { Italy (Campania-south } \\
\text { Tyrrhenian Sea) }\end{array}$ & 2018 & $40^{\circ} 21,505^{\prime} \mathrm{N} 14^{\circ} 59,816^{\prime} \mathrm{E}$ & 1 & & $3-4$ & Current study & 34 \\
\hline
\end{tabular}

* http://www.biodiversidadvirtual.org (visited on 15/3/2018)

Club of Marina di Ragusa $\left(36^{\circ} 46.696^{\prime} \mathrm{N}, 14^{\circ}\right.$ 33.698'E) (Fig. 1) (Table 1).

The morphological features of the specimens were in accordance with those described by BOYKO (2002). The coloration of fresh adult was dorsally brown-reddish, antennular flagellae ringed with purple and yellowish brown (Fig. 2b).

Depths of collection, substrate and values of carapace lengths of our specimens are in agreement with previous records (GIACOBBE \& SPANÒ, 1996; BOYKO, 2002; PEREIRA et al., 2008; CORSINIFOKA \& KALOGIROU, 2013; ABDELSALAM \& RAMADAN, 2017) (Table 1).

The collection of samples using fishing gears set at late afternoon and retrieved at early morning, such as trammel-nets of the present cases, or shrimp trap (CORSINI-FOKA \& KALOGIROU, 2013), could probably indicate an increased activity of the sand crabs during the night. As reported by
McCAWLEY et al. (2006), the red snapper Lutjanus campechanus (Poey, 1860) fed on more watercolumn organisms during the day and more sand- or mud-associated organisms at night, including Albunea paretii Guérin-Méneville, 1853 in Alabama artificial reefs.

The presence of an intense orange coloration in the female MSNC 4553-3, collected in May (Fig. 2c), could suggest the summer season as the reproduction period of the species in the area. Ovigerous females of the albuneid Lepidopa benedicti Schmitt, 1935 were found from late spring through summer at South Padre Island, Texas, on the western coast of Gulf of Mexico (FAULKES, 2017), while Albunea symnista (Linnaeus, 1767) showed two distinct reproductive peaks, one in January and another in July, on Madras coasts, India (SUBRAMONIAN \& PANNEERSELVAM, 1985). 
As mentioned above, A. carabus lives on sandy environments where the water is prevalently turbid, often with high hydrodynamism, including estuaries (GIACOBBE \& SPANÒ, 1996; SPANÒ et al., 1999). In agreement with the above, two of the specimens here described were found close to the mouth of a river.

The species is widely distributed in the Mediterranean Sea, although, up to date, it is not reported from various regions, such as the Libyan coasts and most of the Ionian and Aegean waters (Table 1) (Fig. 1).

The biology of this sand crab deserves to be studied in depth in order to know its circadian rhythm and its reproductive, territorial and feeding activities.

\section{CONCLUSIONS}

The current records significantly amplify our knowledge on the geographical distribution of A. carabus in the shallow soft bottoms of the southern coasts of Sicily and fill a lack of information also for the southeastern Tyrrhenian coasts. Besides scientific biological surveys on benthic fauna, the findings described here attest that information and observations provided by fishery operators and local or tourist citizens involved in diving and fishery and, generally, in marine biology (citizen scientists), represent an incontestably highly valuable support in monitoring marine biodiversity, improving furthermore knowledge on the geographical distribution of species.

\section{ACKNOWLEDGEMENTS}

The authors would like to thank the fishermen Mr. Orazio CAUSARANO, Mr. Ignazio CONTI, Mr. Alessandro CATAUDELLA for providing the samples of Albunea carabus reported in this study. Sincere thanks also to Mr. Calogero PASSANNANTE and the fisherman Mr. Marco CORTESE for providing information on samples collected in 2012 (Sicily) and 2018 (Campania), respectively. We are grateful furthermore to Prof. Charles BOEWE (Pittsburgh, NC, USA) who kindly shared with us many information about C. S. Rafinesque during the Sicilian period and to our friend Prof. Carlo VIOLANI (University of Pavia, Italy), the only Italian biographer of Rafinesque. Dr. Mauro CAVALLARO (University of Messina, Italy) kindly provided a copy of MONCHARMONT (1969) when all other attempts to obtain it failed.

\section{REFERENCES}

ABDELSALAM, K.M. \& S.E. RAMADAN. 2017. First record of two crab species from the Egyptian Mediterranean Sea. Cah. Biol. Mar., 58: 17-23.

AHARONI, I. 1937. Donnés zoogéographiques sur la faune de la Palestine et des contrées adjacentes par rapport à celle de la Péninsule Ibérique. In: J.A. Ricardo (Editor). Comptes Rendus XIIe Congrès International de Zoologie, Lisbonne, 15-21 Septembre 1935, 12(2): 1132-1137.

BOLIVAR, I. 1875. El género Albunea . . . . Anales Soc. Esp. Hist. Nat. (Actas), 4 (3): 20-21. BOYKO, C.B. 2002. A worldwide revision of the recent and fossil sand crabs of the Albuneidae Stimpson and Blepharipodidae, new family (Crustacea: Decapoda: Anomura:
Hippoidea). Bull. Am. Mus. Nat. Hist., 272: 1-396.

CORSINI-FOKA, M. \& S. KALOGIROU. 2013. First record of Albunea carabus (Linnaeus, 1758) (Decapoda: Anomura: Hippoidea) in the Aegean Sea. Cah. Biol. Mar., 54: 297-299.

FAULKES Z. 2017. The phenology of sand crabs, Lepidopa benedicti (Decapoda: Albuneidae). J. Coastal Res., 33 (5): 1095-1101.

GARCIA SOCIAS, L. \& F. GRACIA. 1988. Nuevas aportaciones a la fauna de Crustácea Decápoda de las Islas Baleares. Boletìn de la Sociedad de Historia Natural de Baleares, 32: 47-56.

GIACOBBE, S. \& N. SPANO. 1996. New Records of Albunea carabus (L., 1758) (Decapoda, Anomura) in the Mediterranean Sea. Crusta- 
ceana, 69: 719-726.

HOLTHUIS, L.B. 1954. C.S. Rafinesque as a carcinologist: an annotated compilation of the information on Crustacea contained in the works of that author. Zool. Verhandel., 25 (1): 1-43.

HOLTHUIS, L.B. \& E. GOTTLIEB. 1958. An annotated list of Decapod Crustacea of the Mediterranean Coast of Israel, with an appendix listing the Decapoda of the Eastern Mediterranean. B. Res. Counc. Israel, 7B: 1-126.

KATAĞAN, T. \& C. ÇEVIK. 2003. A new record of Albunea carabus (L., 1758) (Decapoda, Anomura, Hippidea) from the Eastern Mediterranean coast of Turkey. Crustaceana, 76: 637-639.

LARRINÙAY AZCONA, D.A. 1874. D. Ignacio Bolivar, presenta un ejemplar de crustáceo del género Albunea Fab . . . Anales Soc. Esp. Hist. Nat. (Actas), 3(3): 46.

LUCAS, H. 1853. Mélanges et nouvelles. Revue et Magasin de Zoologie Pure et Appliquée, 2nd sér., 5: 45-47.

LUCAS, H. 1849. Crustacés, arachnides, myriapodes et hexapodes. Exploration scientifique de l'Algérie pendant les années 1840, 1841, 1842. Science physique. Zoologie I. Histoire Naturelle des Animaux Articulés, 1: 1-403.

McCAWLEY J.R., COWAN J.H., JR., \& R.L. SHIPP. 2006. Feeding periodicity and prey habitat preference of Red Snapper, Lutjanus campechanus (Poey, 1860), on Alabama Artificial Reefs. Gulf of Mexico Science, 1/2: 14-27.

MILNE-EDWARDS, A. \& E.-L. BOUVIER. 1900. Crustacés Décapodes 1. Brachyoures et Anomures. Expéditions Scientifiques du 'Travailleur' et du 'Talisman' Pendant les Années 1880, 1881, 1882, 1883. Masson et $\mathrm{C}^{\mathrm{ie}}$, Paris, 5: 1-396.

MIRANDA RIVERA, A. de. 1933. Ensayo de un catálogo de crustáceos decápodos marinos de España y Marruecos español. Instituto Español de Oceanografía, Notas y resúmenes, ser. 2, 67: 1-72. (A. symnista, de Menorca)

MONCHARMONT, U. 1969. Sulla prezenza di Albunea carabus (L., 1758) nel Mediterraneo (Crustacea, Decapoda, Anomura). Pubbl. Staz. Zool. Napoli, 37: 434-440.
MURA, M. \& S. CORDA. 2011. Crustacea Decapoda in the Sardinian Channel: A Checklist. Crustaceana, 84 (5/6): 667-687.

MURPH, G.H. \& Z. FAULKES. 2013. Abundance and size of sand crabs, Lepidopa benedicti (Decapoda: Albuneidae), in Southern Texas. Southwest Nat., 58 (4): 431-434.

PEREIRA, A.M., M.M. RUFINO \& M.B. GASPAR. 2008. First record of Albunea carabus (Decapoda, Anomura, Hippidea) from the Algarve coast, South Portugal. Mar. Biol. Res., 4: 236-238.

RAFINESQUE, C.S. 1814. Précis de découvertes et travaux somiologiques de Mr C. S. Rafinesque-Schmaltz entre 1800 et 1814. Ou choix raisonné de ses principales découvertes en zoologie et en botanique, pour servir d'introduction à ses ouvrages futurs. Royale Typographie Militaire, Palerme, $55 \mathrm{pp}$.

RAFINESQUE, C.S. 1815. Analyse de la Nature ou tableau de l'univers et des corps organisés. Tip. Jean Barravecchia, Palermo, 223 pp.

RUBIÒ, M. \& L.B. HOLTHUIS. 1972. New records of Albunea carabus (L.) from Spanish waters (Decapoda, Anomura, Hippidea). Thalassia Jugosl., 8 (1): 41-47.

SCUDERI, D., A. VILLARI \& M. ANGELICO. 2017. A massive record of the rare 'mole crab' Albunea carabus (Decapoda: Anomura: Hippoidea) along the sandy coasts of Catania. Bulletin of the Entomological Society of Malta, 9: 43.

SERIDJI, R. 1988. Some planktonic larval stages of Albunea carabus (L., 1758) (Crustacea, Decapoda, Anomura). J. Nat. Hist. London, 22 (5): 1293-1300.

SPANÒ, N., P. RINELLI \& S. RAGONESE. 1999. The first find of Albunea carabus (Decapoda, Anomura) on the southern Sicilian coasts (Strait of Sicily, Mediterranean Sea). In: F.R. Schram \& J.C. von Vaupel Klein (Editors). Crustaceans and the Biodiversity Crisis: Proceedings of the $4^{\text {th }}$ International Crustacean Congress, Amsterdam, the Netherlands, 20-24 July 1998, Brill, Leiden, pp. 617-621.

SUBRAMONIAN T. \& M. PANNEERSELVAM. 1985. Semi-annual breeding pattern in the burrowing sand crab Albunea symnista (L.) (= 
symnista) on Madras coast. Indian J. Mar.

Sci., 14: 226-227.

SWAINSON, G.M. (Editor). 1989. William Swainson,

Naturalist and Artist. Diaries 1808-1818:

Sicily, Malta, Greece, Italy and Brazil. Privately published, Palmerston North, New

Zealand, $182 \mathrm{pp}$.
ZARIQUIEY-ALVAREZ, R. 1961. Decápodos españoles. XV. Sobre un raro Crustáceo decápodo: Albunea carabus (L., 1758). Invest. Pesq., 19: 103-110.

Received : 12 July 2018

Accepted : 4 January 2019

\title{
Dodatni nalaz vrste, Albunea carabus (Linnaeus, 1758) (Decapoda, Anomura, Hippoidea) u talijanskim vodama
}

\author{
Bruno ZAVA, Gianni INSACCO i Maria CORSINI-FOKA*
}

*Kontakte-pošta: mcorsini@hcmr.gr

\section{SAŽETAK}

Autori dokumentiraju dodatne nalaze vrste Albunea carabus (Linnaeus, 1758) s jugoistočnih obala Sicilije, poboljšavajući tako znanje o rasprostranjenosti ove slabo poznate vrste oko otoka i u Sredozemnom moru. Ažurirana je distribucija zapisa u cijelom bazenu.

Ključne riječi: rakovi, Anomura, Albunea carabus, Sicilija, Sredozemno more 